\title{
Jilbab dalam al-(Qur'an dan Relevansinya dengan Pendidikan Islam
}

\author{
Sain Hanafy \\ Universitas Islam Negeri (UIN) Alauddin Makassar \\ sainha503@gmail.com
}

Abstract: This article shows that: the concept of Quran about the veil not only instructs women to wear the hijab, but also to the believing men and women of Muslims to adorn themselves with piety jewelry. The concept of the veil was ordered not to say in a voice seductive, stimulating and provoke lust, stay indoors, not out except in a situation that really needs, not tabarruj, not open-aperture, establish prayers, pay zakat, submit and obey all which Allah recommended to His Apostle to what came to him. The relevance of the concept of Qur'an about the veil with the goal of Islamic education is its compatibility in the formation of human morality that leads to the personality of Islam by always strengthening the faith and piety, so as to be useful human beings for the state, religion and achieve happiness of the world and the hereafter. Vocabulary education is philosophically oriented towards Islamic values based on three dimensions, (a) inculcating a balanced and harmonious relationship with God, (b) establishing a harmonious, harmonious and balanced relationship with the community, (c) developing the ability to explore, managing, and utilizing the natural wealth for the benefit of the welfare of his life with a harmonious attitude.

Keywords: Hijab Philosophy, Islamic Education, and Values in the Quran. 


\section{Pendahuluan}

Siapa saja yang merasa memeluk agama Islam, maka berkewajiban menerima hukum serta ketetapan agamanya. Meskipun ketetapan-ketetapan tersebut akan mengurangi kebebasan manusia dalam bertindak, karena hukum adalah aturan yang berisi perintah dan larangan. Namun demikian, tidak ada hukum Islam yang diberlakukan pada pemeluknya bertujuan mengekang kebebasan, melainkan melalui cara tersebut manusia akan memperoleh yang terbaik dalam hidupnya. Ketentuan yang ada dalam agama adalah ketentuan Tuhan yang maha mengetahui yang terbaik bagi hamba-hamba-Nya. Andai kata kita merasa ketentuan tersebut mengekang kebebasan, maka pada saat yang sama agama bermaksud memberi kita yang terbaik dan menghindarkan umatnya dari kubangan dosa. Di sinilah perlu disadari bahwa setiap ajaran yang disampaikan para Rasul memiliki aturan dan metode dalam menyikapi kehidupan. ${ }^{1}$

Setiap perintah yang Allah turunkan kepada para hamba-Nya pasti selalu ada kebaikan, dan setiap yang dilarang pasti ada hikmahnya. Segala sesuatu yang mengandung kemaslahatan atau kemaslahatannya lebih besar dari pada kerusakannya, maka hal tersebut tidak mustahil jika diperintahkan oleh Allah baik bersifat wajib ataupun sunnah. Begitu sebaliknya, jika segala sesuatunya mengandung mudarat, keburukan, kerusakan, bencana, dan bahkan hal tersebut sangat berdominan, maka hal tersebut dilarang bahkan diharamkan, ini semua untuk menjaga kehormatan dan demi kebaikan kehidupan manusia di dunia. Begitu halnya dengan jilbab, jilbab merupakan salah satu persoalan yang sangat penting dalam dunia Islam. Oleh sebab itu, kaum wanita (Muslimah) dianjurkan untuk selalu mengenakan jilbab dalam keadaan apapun dan di manapun mereka berada. Karena jilbab di sini lebih banyak mengandung kemaslahatan dari padamudaratannya. ${ }^{2}$ Di antaranya selain untuk menutup aurat juga sebagai identitas bagi kaum wanita Muslimah agar

\footnotetext{
1 Syeikh Mutawalli Syảrawi, Problematika Wanita (Jakarta: Iqra' Insan Press, 2003), 102-103.

2 Tim Redaksi, al-Qur'an al-Karim (Solo: Qomari, t.t), 340.
} 
mudah untuk dikenali dan tidak diganggu. Sebagaimana firman Allah dalam surat al-Ahzab: 59, "Wahai Nabi, katakanlah kepada istri-istrimu, anak-anak perempuanmu dan istri-istri orang mukmin: 'Hendaklah mereka mengulurkan jilbabnya ke seluruh tubuh mereka.' Yang demikian itu supaya mereka lebih mudah untuk dikenal, karena itu mereka tidak diganggu. Dan Allah adalah Maha Pengampun lagi Maha Penyayang."3

Namun demikian, kondisinya di tengah-tengah masyarakat pada saat ini sangat memprihatinkan. Ada beberapa kalangan yang menolak kewajiban mengenakan jilbab bagi setiap Muslimah, ${ }^{4}$ ada yang mau mengenakannya akan tetapi tidak mengikuti aturan-aturan berjilbab dalam syariat Islam, mereka berpakaian sekaligus telanjang, dalam arti mereka mengenakan jilbab akan tetapi mereka berpakaian yang transparan dan ketat yang dapat menimbulkan nafsu dan syahwat kaum pria untuk menikmatinya, dan yang bisa menimbulkan perzinaan. Ada pula di antara mereka yang beranggapan bahwa ajaran yang mewajibkan kaum wanita untuk menutup diri, tidak bebas bergaul dengan laki-laki, dan lebih banyak berdiam diri di rumah adalah ajaran kuno. Hal ini merupakan akibat dari pengaruh budaya Barat yang sudah sangat mengakar dalam kehidupan masyarakat Indonesia. Selama ini banyak kalangan yang rancu dalam memahami hakikat jilbab yang sesungguhnya. Mereka menganggap bahwa dengan mengenakan sehelai kain yang diikat ke belakang dan dikombinasikan dengan kaos ketat plus celana pensil berarti telah berjilbab. Ini jelas pemahaman yang keliru dan sangat jauh dari misi disyariatkannya jilbab itu sendiri. Karenanya, cara berjilbab yang salah kaprah seperti ini justru menimbulkan citra yang tidak baik terhadap Muslimah berjilbab sebab kenyataannya di lapangan membuktikan bahwa banyak dari Muslimah berjilbab model tadi ternyata akhlaknya

3 Fadhal AR, Al-Qur'an dan Terjemahnya (Surabaya: Mekar, 2004), 330.

4 "Aku tahu ada undang-undang, aku tahu ada Islam, tapi aku tidak peduli, karena aku punya mau dan bebas melakukan apapun, bebas pergi kemanapun, bebas mengenakan pakaian model apapun, bebas memiliki apapun, bebas dalam segala hal tanpa ada yang berhak mengatur dan membatasinya." Luqman Haqani, Aku Bukan Muslimah: JebakanJebakan yang Menghancurkan Identitas Muslimah (Bandung: Pustaka Ulumuddin, 2004). 
memprihatinkan. Mereka terlihat bebas bergaul dengan lawan jenis, bahkan sebagiannya sampai hamil di luar nikah. Akibatnya masyarakat memandang bahwa jilbab tidak ada artinya bagi jati diri seseorang. Karena toh mereka sama saja kelakuannya dengan yang tidak berjilbab sebab oknum pemakai jilbab ini mengunggulkan kebebasan yang tidak sesuai dengan syari'at Islam, malah mereka berlindung dengan jilbab, berpura-pura memakai jilbab hanya untuk menutupi kelakuan bejatnya, atau bahkan mereka sengaja ingin merusak nama baik jilbab. ${ }^{5}$

Dalam Islam, kebebasan manusia itu berarti manusia mampu mengendalikan dirinya dengan gerakannya dalm ruang lingkup batas-batas syariat yang diwajibkan oleh Allah untuk menghormatinya, baik dalam bentuk pelaksanaan maupun dalam bentuk peninggalan. Kemudian, hijab atau jilbab yang dipakai oleh wanita tidak sampai merebut kebebasan mereka. Kebebasan tersebut ditentukan oleh mobilitas wanita dalam bekerja, dan itu adalah hal yang tidak terhambat dengan adanya hijab atau jilbab. Sesungguhnya sejarah Islam kita membuktikan bahwa wanita dapat bekerja di sektor pertanian dan sektor konveksi, serta di sebagian sektor industri yang ada saat itu, tanpa aktivitasnya terhambat oleh dampak negatif jilbab, bahkan ia (wanita) seringkali mengungguli pria dengan tetap memakai jilbabnya. Yang menjadi permasalah sekarang adalah para wanita sangat salah kaprah dalam mengartikan jilbab, mereka mengenakan jilbab tidak sesuai dengan syariat Islam. Maka perlu diadakannya bimbingan untuk memperbaiki akhlak mereka dan ini bisa diwujudkan melalui dunia pendidikan, salah satunya pendidikan Islam. Pendidikan Islam berhubungan erat dengan agama Islam itu sendiri, lengkap dengan akidah, syariat, dan sistem kehidupannya. Keduanya ibarat dua kendaraan yang berjalan di atas dua jalur seimbang, baik dari

\footnotetext{
5 Praktik semacam ini sama sekali tidak terbatas diJerman saja tapi tersebar hampir di seluruh Eropa bagian utara. Kulminasi pergerakan ini diawali dengan emansipasi kaum wanita dan kebebasan kaum laki-lakinya. Dunia sebagai tempat manusia berbaju, praktik Nudisme kadang-kadang terlihat mempunyai aspek kelucuan. Lebih daripada itu, Nudisme memperlihatkan secara samar kembalinya manusia pada masa kebinatangan, kehidupan liar, yang hanya membuat malu. Abul A'la Maududi, Jilbab Wanita dalam Masyarakat Islam, terj. Mufid Ridho (Bandung; Marja, 2005), 10.
} 
segi tujuan maupun rambu-rambunya yang disyariatkan bagi hamba Allah yang membekali diri dengan takwa, ilmu, hidayah, serta akhlak untuk menempuh perjalanan hidup. Sebagaimana firman Allah dalam al-Qur'an Surat al-Baqarah ([2]: 197) sebagai berikut:

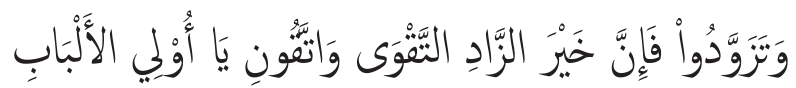

Berbekallah, dan sesungguhnya sebaik-baik bekal adalah takwa, dan bertakwalah kepada-Ku wahai orang-orang yang berakal.

Untuk mengarahkan peserta didik, diperlukan adanya tujuan pendidikan tersebut karena sebuah usaha yang tidak mempunyai tujuan, maka tidak akan mempunyai arti apa-apa. Lebih lanjut, akan dieksplorasi peranan jilbab dalam kehidupan secara lebih komprehensif.

\section{Makna Jilbab}

Secara bahasa, jilbab berasal dari bahasa Arab yaitu dari kata jalbaba-yujalbibu-jalbabatan, yang artinya menutup, kata dasar ini mengikuti wazan "fa'lala". Dan ada juga yang ikut wazan "tafa'lala", yaitu dari kata dasar tajalbaba-yatajalbabu-tajalbuban atau berjilbab. ${ }^{6}$ Sebelum sampai pada pemaknaan jilbab, akan diuraikan terlebih dahulu makna pakaian dalam al-Qur'an karena jilbab adalah salah satu jenis pakaian. Paling tidak Al-Qur'an telah menggunakan tiga istilah untuk pakaian, yaitu libas, tsiyab dan sarabil. Libas adalah penutup, apapun yang ditutup, meskipun hanya sebagian, seperti cincin yang dipakai di jari manis. Dalam al-Qur'an kata libas digunakan untuk menunjukkan pakaian lahir maupun batin, seperti takwa yang dalam al-Qur'an Surat al-A'raf ([7]: 26) disebut juga dengan libasut taqwa. Berbeda dengan kata libas, kata tsiyab dalam Surat al-Muddatsir ([84]: 4) hanya menunjukkan pada pakaian lahir. Kata ini diambil dari kata tsaub yang berarti kembali,

${ }^{6}$ AW. Munawwir dan Muhammad Fairuz, Kamus Al-Munawwir Indonesia-Arab Lengkap (Surabaya: Pustaka Progresif, 2007), 365. 
yakni kembalinya sesuatu pada keadaan semula atau pada keadaan yang seharusnya sesuai pada ide pertanyaannya.

Ide dasar pakaian berdasarkan Surat al-A'raf ([7]: 20-22) yang mengisahkan tentang Adam dan Hawa bahwa ide dasar pakaian adalah untuk menutup aurat. Namun, karena godaan setan, aurat manusia menjadi terbuka (atau kalau sekarang dibuka). Dengan demikian, aurat yang ditutup dengan pakaian, akan dikembalikan pada ide dasarnya, yaitu untuk ditutup, bukan untuk dibuka apalagi untuk dipamerkan. Ayat itu juga menegaskan bahwa menutup aurat adalah fitrah manusia yang diaktualkan pada saat ia memiliki kesadaran. Dengan demikian, ide membuka aurat adalah ide setan, dan karenanya tanda-tanda kehadiran setan keterbukaan aurat. Kata yang ketiga adalah sarabil. Kata ini berarti pakaian, apapun jenis dan bahannya. Dalam al-Qur'an kata ini hanya disebut dua kali. Dalam Surat an-Nahl ([16]: 81) dijelaskan sarabil adalah pakaian yang berfungsi untuk menangkal sengatan panas, dingin dan bahaya dalam peperangan. Dalam Surat Ibrahim ([14]: 50) dijelaskan tentang siksa yang akan dialami oleh orang-orang berdosa kelak pakaian mereka dari pelangkin. Dari sini dipahami bahwa pakaian ada yang menjadi alat penyiksa. Siksa tersebut karena yang bersangkutan melakukan dosa dan diganjar oleh Allah di neraka.

Makna jilbab dalam bahasa Indonesia berbeda dengan makna dari para ulama. Makna-makna jilbab antara lain baju yang longgar atau kerudung penutup kepala wanita, pakaian yang menutupi baju dan kerudung yang dipakai, semua pakaian yang menutupi aurat wanita. Jilbab secara istilah, para ahli bahasa berbeda-beda dalam mendefinisikan jilbab akan tetapi dengan makna dan tujuan yang sama. Menurut al-Biqa'i yang dikutip oleh Quraish Shihab dalam Tafsir al-Misbah bahwa jilbab adalah pakaian yang menutupi baju dan kerudung atau semua pakaian yang menutupi wanita. ${ }^{7}$ Menurut Ahmad Mustofa al-Maragi dalam Tafsir al-Maragi mengatakan bahwa jilbab adalah baju kurung yang meliputi seluruh tubuh wanita, lebih dari sekadar baju biasa dan kerudung. ${ }^{8}$

\footnotetext{
7 Quraish Shihab, Tafsir al-Misbah, Volume II (Jakarta: Lentera Hati, 2002), 214.

8 Ahmad Mustofa al-Maragi, Tafsir Al-Maragi, Juz. XXII, 61 .
} 
Dari beberapa definisi di atas dapat diambil kesimpulan bahwa jilbab yaitu pakaian yang menutupi aurat wanita. Jilbab adalah pakaian lebar dan sekaligus kerudung (penutup kepala). Jilbab dalam bahasa Arab disebut juga sebagai hijab yang hampir sama dengan satir, yaitu keterpisahan (pemisah) atau penutup. Ada juga yang mengartikan jilbab sebagai penutup wajah, apapun yang diartikan oleh para ahli memiliki maksud yang sama yaitu sebagai penutup aurat.

\section{Pendidikan Islam}

Masalah pendidikan menjadi prioritas utama sejak awal kehidupan manusia. Bahkan, Nabi Muhammad Rasulullah Saw. sendiri telah mengisyaratkan bahwa proses belajar bagi setiap insan adalah sejak ia masih dalam kandungan ibunya sampai liang kuburnya, dan sejak dari rumah tangga orang tuanya hingga jauh ke lain Negara. Sebagai agama yang mengutamakan pendidikan, maka sepanjang kurun kehidupan Islam hingga kini telah muncul banyak ahli yang menyumbangkan buah pikirannya dalam bidang pendidikan khususnya, dan dalam berbagai bidang lain pada umumnya. Pendidikan Islam yaitu pendidikan yang berbasis agama Islam. Dalam buku Crisis in Muslim Education dijelaskan, "Islamic Education is an education which trains the sensibility of pupils in such a manner that in their attitude to life, their actions, decisions and approach to all kinds of knowledge, they are governed by the spiritual and deeply felt ethical values of Islam ${ }^{9}$ (Pendidikan Islam adalah pendidikan yang melatih kepekaan pengikutnya terhadap permasalahan seperti sikap hidup, perbuatan dan keputusan mereka serta pendekatan terhadap setiap ilmu, mereka diatur dan diisi dengan etika-etika Islam)."

Secara etimologis, pengertian pendidikan Islam digali dari al-Qur'an dan Hadis sebagai sumber pendidikan Islam. Menuntut atau mencari ilmu merupakan kewajiban bagi setiap Muslim dan Muslimah (tanpa membedakan jenis kelamin) dasarnya terdapat baik dalam al-Qur'an

\footnotetext{
9 Syed Sajjad Husain \& Syed Ali Ashraf, Crisis in Muslim Education (Jeddah: Hodder and Stoughton, t.t), 1.
} 
maupun Hadis. Dari kedua sumber tersebut, ditemukan ayat-ayat atau Hadis-Hadis yang mengandung kata-kata atau istilah-istilah yang pengertiannya terkait dengan pendidikan Islam, misalnya tarbiyah, ta'lim, dan ta'dib. Bertolak dari tinjauan etimologi ini, kata Islam yang melekat dalam pendidikan Islam adalah pendidikan yang berwarna Islam, pendidikan Islam adalah pendidikan yang didasarkan Islam yang bersumber dari al-Qur'an dan al-Hadis. Sebagaimana dikemukakan oleh Ahmad Tafsir bahwa ilmu pendidikan Islam adalah ilmu yang berdasarkan al-Qur'an, Hadis dan akal. ${ }^{10}$ Menurut tinjauan terminologis, para ahli memberikan beragam pendapat dalam memberikan makna pendidikan Islam, di antaranya Achmadi mendefinisikan bahwa pendidikan Islam adalah segala sesuatu untuk menjaga fitrah manusia, serta sumber daya insani yang ada padanya menuju terbentuknya manusia seutuhnya (insan kamil) sesuai dengan norma Islam. ${ }^{11}$ Pengertian yang dikemukakan Achmadi tersebut mengandung arti bahwa dalam proses pendidikan Islam terdapat usaha memelihara kesucian manusia. Hal itu merupakan fitrah yang ada sejak lahir serta mengembangkan segala potensi jiwa yang terdapat padanya melalui segenap usaha, sehingga manusia tersebut terbentuk menjadi manusia yang sempurna berdasarkan pandangan Islam. Pendidikan Islam adalah upaya mengembangkan, mendorong, serta mengajak manusia lebih maju dengan berlandaskan nilai-nilai yang tinggi dan kehidupan yang mulia, sehingga terbentuknya pribadi yang lebih sempurna, baik yang berkaitan dengan akal, perasaan maupun perbuatan. Definisi ini mempunyai beberapa prinsip yang dikemukakan dalam pendidikan Islam yaitu; pendidikan merupakan proses perbantuan pencapaian tingkat keimanan dan berilmu yang disertai dengan melakukan amal shalih. Dan konsep-konsep nilai dalam pendidikan Islam adalah nilai-nilai agama Islam yang berlandasan al-Qur'an dan Hadis.

Sedangkan menurut Achmad D. Marimba pendidikan Islam adalah bimbingan jasmani dan rohani berdasarkan hukum-hukum agama

\footnotetext{
${ }^{10}$ Ahmad Tafsir, Ilmu pendidikan dalam Perspektif Islam (Bandung; Remaja Rasda Karya, 2010), 12.

${ }^{11}$ Achmadi, Ideologi Pendidikan Islam (Yogyakarta; Pustaka Pelajar, 2005), 28.
} 
Islam menuju terbentuknya kepribadian yang utama menurut ukuranukuran Islam. Dalam definisi ini terlihat jelas bahwa pendidikan Islam itu membimbing anak didik dalam perkembangan dirinya baik jasmani maupun rohani menuju terbentuknya kepribadian yang utama pada anak didik nantinya yang didasarkan pada hukum-hukum dalam agama Islam. Walaupun istilah pendidikan Islam tersebut dapat dipahami secara berbeda, tetapi pada hakikatnya merupakan satu kesatuan dan mewujud secara operasional dalam satu sistem yang utuh. Konsep dan teori kependidikan Islam sebagaimana yang dibangun atau dipahami dan dikembangkan dari al-Qur'an dan Sunnah, mendapatkan justifikasi dan perwujudan secara operasional dalam proses pembudayaan dan pewarisan serta pengembangan ajaran agama, budaya dan peradaban Islam dari generasi ke generasi, yang berlangsung sepanjang sejarah umat Islam. ${ }^{12}$ Kalau definisi-definisi itu dipadukan, maka tersusun suatu rumusan tentang pendidikan Islam. Yaitu, bahwa pendidikan Islam ialah mempersiapkan dan menumbuhkan anak didik atau individu manusia yang prosesnya terjadi secara terus menerus sejak ia masih dalam kandungan sampai masuk liang kubur. Yang dipersiapakan dan ditumbuhkan meliputi aspek jasmani, akal, dan rohani sebagai satu kesatuan tanpa mengesampingkan salah satu aspek, dan melebihkan aspek yang lain. Persiapan dan pertumbuhan itu diarahkan agar menjadi manusia yang berdaya guna dan berhasil guna bagi dirinya dan bagi umatnya, serta dapat memperoleh suatu kehidupan yang sempurna. Dari berbagai pengertian yang telah dipaparkan oleh para ahli di atas dapat disimpukan bahwa pendidikan secara umum adalah proses yang dilakukan secara sadar untuk memperoleh kehidupan yang lebih baik. Adapun pendidikan Islam yaitu pendidikan yang bernuansa Islam, membimbing peserta didik untuk lebih maju dalam pengembangan dirinya baik jasmani maupun rohani, mengembangkan potensi manusia yang ada padanya sesuai dengan al-Quran dan Hadis.

\footnotetext{
${ }^{12}$ Muhaimin, Paradigma Pendidikan Islam Upaya Mengefektifkan Pendidikan Agama Islam di Sekolah (Bandung: PT. Remaja Rosdakarya, 2008), 30.
} 


\section{Konsep Jilbab dalam al-Qur'an}

Sebagaimana yang telah diketahui bersama bahwa al-Qur'an diyakini umat Islam sebagai Kalamullah (firman Allah) yang mutlak benar, berlaku sepanjang zaman dan mengandung ajaran dan petunjuk tentang berbagai hal yang berkaitan dengan kehidupan manusia di dunia dan akhirat. Ajaran dan petunjuk al-Qur'an tersebut berkaitan dengan berbagai konsep yang amat dibutuhkan oleh manusia dalam mengarungi kehidupannya di dunia dan di akhirat. Al-Qur'an adalah sebuah kalam Allah Swt. yang menggunakan dimensi-dimensi kemanusiaan, kekinian, dan keduniawian agar mudah dipelajari, dipahami, dan diamalkan. Namun demikian, al-Qur'an bukanlah kitab suci yang siap pakai, dalam arti berbagai konsep yang dikemukakan al-Qur'an tersebut mau tidak mau seseorang harus melewati jalan tafsir sebagaimana telah dilakukan para ulama. Sesuai perkembangan masyarakat yang seamakin dinamis sebagai akibat kemajuan ilmu dan teknologi informasi, maka aktualisasi nilai-nilai al-Qur'an menjadi sangat penting. Karena tanpa aktualisasi kitab ini, umat Islam akan mengalami kendala dalam upaya internalisasi nilai-nilai al-Qur'an sebagai upaya pembentukan pribadi umat yang beriman, bertakwa, berakhlak mulia, maju dan mandiri. Secara normatif, tujuan yang ingin dicapai dalam proses aktualisasi nilai-nilai al-Qur'an dalam pendidikan Islam meliputi dimensi-dimensi dan aspekaspek kehidupan yang harus dibina dan dikembangkan oleh pendidikan Islam. Adapun analisis konsep al-Qur'an tentang jilbab dan relevansinya dengan tujuan pendidikan Islam itu sendiri, yaitu konsep jilbab dalam sl-Qur'an tidak hanya terkait dengan pakaian fisik saja, akan tetapi juga pakaian non fisik (ketakwaan) yang wajib dipakai oleh setiap umat Islam.

\section{Jilbab secara Fisik}

Ayat-ayat jilbab menjelaskan tentang pakaian atau busana yang sepatutnya dipakai orang-orang yang beriman, agar berbeda dengan yang tidak beriman atau singkatnya mengenai busana Muslim dan Muslimah. Sebagaimana dijelaskan sebelumnya bahwa berpakaian adalah fitrah, karena itu pada hakikatnya manusia yang sehat fitrahnya dia tidak akan 
telanjang. Meski demikian, tidak semua orang yang berpakaian termasuk dalam kategori berpakaian dalam Islam. Hal ini seperti ditegaskan dalam ayat bahwa berjilbab sekalipun belum tentu sesuai dengan konsep alQur'an tentang jilbab, bila jilbabnya belum diulurkan seperti kebanyakan jilbab gaul sekarang ini. Lebih-lebih yang tidak pakai jilbab. Dari ayatayat tentang jilbab ini, para ulama menjabarkannya dan menentukan syarat-syarat jilbab yang sesuai dengan syariat Islam juga etika-etika yang terkandung di dalamnya. Kesimpulan ini berdasarkan atas pemaparan Wahyono Abdul Ghofur dalam bukunya Tafsir Sosial bahwa salah satu cara untuk menghindari penghinaan, pelecehan dan godaan adalah dengan memakai pakaian yang tidak menggoda, di antaranya jilbab. ${ }^{13}$ Serta pemaparan Abdullah al-Taliyadi bahwa jilbab yakni "pakaian lebar yang dipakai perempuan dan menutupi seluruh tubuh mereka, seperti baju kurung, selimut tebal dan lain sebagainya". ${ }^{14}$ Makna jilbab secara fisik ini terdapat pada kata wal yadh-ribna bi khumurihinna 'ala juyubihinna dalam Surat an-Nur ([24]: 32) yang artinya dan hendaklah mereka menutupkan kain kudung ke dadanya. Quraish Shihab mengatakan bahwa kata khumur adalah bentuk jamak dari kata khimar yang artinya tutup kepala yang panjang, dan kata juyub bentuk jamak dari jayb yang artinya lubang di leher baju. Ahmad Mustofa al-Maragi dalam Tafsir al-Maragi mengartikan dengan "dan hendaklah mereka mengulurkan kerudungnya ke dada bagian atas di bawah leher, agar dengan demikian mereka dapat menutupi rambut, leher dan dadanya sehingga tidak sedikitpun daripadanya yang terlihat." ${ }^{15}$ Dia berkata bahwa ketika Allah menurunkan ayat ini, para kaum wanita Muhajirat segera mengambil pakaian bulu mereka lalu berkerudung dengannya. Makna jilbab secara fisik ini juga terdapat pada kata yudnina alaihinna min jalabibihinna yang artinya hendaklah mereka mengulurkan jilbabnya. Dari pemaparan tersebut dapat diketahui bahwa jilbab secara fisik adalah pakaian yang dapat menutup aurat.

\footnotetext{
${ }^{13}$ Wahyono Abdul Ghafur, Tafsir Sosial (Yogyakarta: eLSAQ Press, 2005), 132.

${ }^{14}$ Abdullah al-Taliyadi, Astagfirullah Aurat (Yogyakarta: Diva Press, 2008), 138.

${ }^{15}$ Ahmad Mustofa al-Maragi, Tafsir al-Maragi (Semarang: PT Karya Toha Putra, 1993), 180.
} 


\section{Jilbab Secara non Fisik}

Makna jilbab secara non fisik terdapat pada kata inittaqoitunna dalam Surat al-Ahzab ([33]: 32) yang artinya jika kamu bertakwa. Quraish Shihab mengrtikan kata ini yakni menghindari segala yang mengundang murka Allah dan Rasul-Nya. Yang bertujuan mendorong mereka untuk lebih meningkatkan ketakwaan. ${ }^{16}$ Kata ziinah yang berarti perhisan, hal ini didasarkan pada penjelasan Saad Shadiq Muhammad bahwa menurut dia, zinah terbagi menjadi dua, yaitu zinah maknawi dan zinah indrawi. Zinah maknawi yaitu perhiasan akhlak (perhiasan yang mengarah kepada akhlak dan moral) dimana seorang perempuan akan menghiasi dirinya dengan hiasan-hiasan ini ketika bergaul dan berusaha. ${ }^{17}$ Tidak diragukan lagi, Islam mendeklarasikan kemerdekaan bagi setiap pemeluknya, merdeka dalam akidah, merdeka dalam berpendapat, bertempat tinggal dan segala bentuk kemerdekaan-kemerdekaan lainnya. Namun ketika seseorang mengekspresikan kemerdekaannya dengan tidak mengindahkan sama sekali aturan-aturan main yang telah ditetapkan Islam, yang dengannya diharapkan kehidupan masyarakat tertata rapi, harmonis, maka kemerdekaan akan berbalik menjadi kebebasan tanpa batas dan penghalalan segala macam cara, yang tentu ini sebagai awal malapetaka.

Islam membangun masyarakat yang bersih dan suci, tidak ada di dalamnya sesuatu yang memancing syahwat (nafsu birahi) walaupun hanya sekejap sekalipun. Oleh karena itu, segala bentuk perilaku yang memancing syahwat seperti pandangan nakal, lenggak-lenggok tubuh, mempertontonkan perhiasan, menampakkan anggota tubuh terlarang atau telanjang, selamanya diupayakan untuk dikendalikan. Karena pelanggaran perzinaan dapat dimulai dari pandangan mata, kata-kata mesra, pergaulan bebas dan mencampur-adukkan dua manusia berbeda jenis, memperlihatkan bagian-bagian tubuh terlarang yang sebagai tempat-tempat merebaknya fitnah, untuk itu Allah menurunkan kalamkalam-Nya tentang jilbab agar manusia terhindar dari bahaya perzinaan

\footnotetext{
${ }^{16}$ Quraish Shihab, Tafsir al-Misbah (Jakarta: Lentera Hati, 2002), 262.

${ }^{17}$ Sa'ad Shadiq Muhammad, Harkat Wanita dalam Islam, 151.
} 
dan rusaknya moral, serta tatanan masyarakat, perintah yang pertama yaitu: Menahan Pandangan dan menjaga kemaluan bagi kaum lelaki sebagaimana yang dijelaskan dalam al-Qur'an surat an-Nur ([24]: 30), dalam ayat berikutnya Allah juga memberikan perintah yang sama kepada kaum perempuan dan larangan memamerkan perhiasan di luar lingkungannya. Menurut al-Maragi dalam Tafsir al-Maragi, dia menyatakan bahwa dalam ayat-ayat sebelumnya Allah telah melarang memasuki rumah, kecuali setelah meminta izin dan mengucapkan salam kepada penghuninya. Hal itu dimaksudkan untuk menghindarkan terjadinya desas-desus buruk dan untuk tidak melihat-lihat aurat serta rahasia orang lain. Selanjutnya, dalam ayat-ayat ini Allah memerintahkan kepada rasulNya agar memberi petunjuk kepada kaum Mukminin untuk menahan pandangannya dari melihat hal-hal yang diharamkan untuk dilihat karena alasan tersebut. Sebab, barangkali hal itu dapat menjerumuskan ke dalam berbagai kerusakan dan merusak berbagai kesucian yang dilarang oleh agama. ${ }^{18}$

Dari sini dapat diketahui dengan jelas, betapa Islam sangat menjaga kehormatan menusia, menghindarkan manusia dari perbuatan zina dengan cara menahan pandangan, tidak melihat aurat yang dapat menimbulkan fitnah. Seorang wanita Muslimah harus benar-benar bisa menjaga auratnya, menutupi seluruh bagian tubuh yang dapat merangsang lakilaki. Menurut Teungku Muhammad Hasbi dalam tafsirnya al-Qur'anul Majid an-Nur, dia berpendapat bahwa dalam ayat-ayat ini Allah menyuruh para mukmin memejamkan mata dari melihat bagian-bagian badan orang lain yang menjadi aurat baginya. Sebab melihat bagian aurat dalam keadaan terbuka bisa mendatangkan kemaksiatan. Selain itu, Allah juga menjelaskan orang-orang yang boleh melihat bagian-bagian badan yang menjadi tempat hiasan bagi seorang perempuan, ${ }^{19}$ dan ayat berikutnya an-Nur ([24]: 60) Allah memberikan pengecualian terhadap orang-orang

${ }^{18}$ Ahmad Mustafa al-Maragi, Tafsir Al-Maragi (Semarang: PT Karya Toha Putra, 1993), 175-176.

${ }^{19}$ Teungku Muhammad Hasbi Ash-Shiddiegy, Tafsir al-Quranul Majid an-Nuur (Semarang: Pustaka Rizk Putra, 2000), 2819. 
tua yang sudah tidak memiliki ketertarikan kepada laki-laki dan lakilakipun tidak memilki ketertarikan terhadapnya untuk menanggalkan jilbabnya.

Dari penjabaran ayat-ayat di atas dapat diketahui bahwa perhiasan yang telah ditetapkan syar'i adalah hiasan keislaman, keimanan, ketaatan, sabar, kekhususan, shadaqah, puasa, dan menjaga kemaluan. Sebagaimana firman Allah dalam al-Qur'an Surat al-Ahzab ([33]: 35).

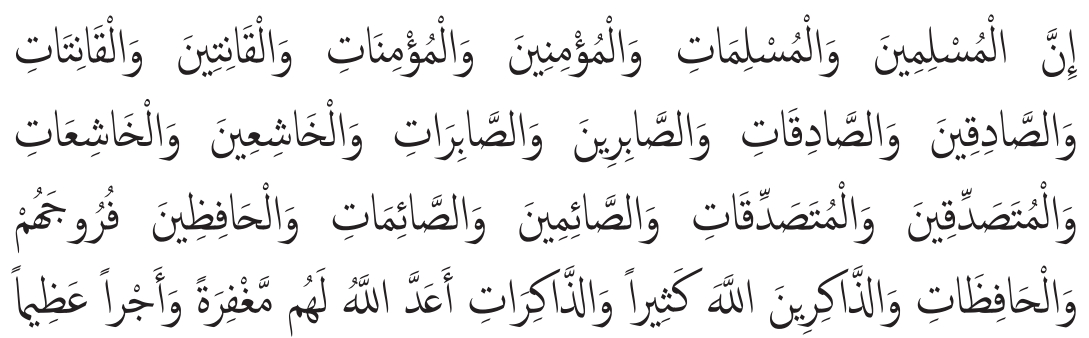

Sesungguhnya laki-laki dan perempuan yang Muslim, laki-laki dan perempuan yang mukmin laki-laki dan perempuan yang tetap dalam ketaatannya, laki-laki dan perempuan yang benar, lakilaki dan perempuan yang sabar, laki-laki dan perempuan yang khusyuk, laki-laki dan perempuan yang bersedekah, laki-laki dan perempuan yang berpuasa, laki-laki dan perempuan yang memelihara kehormatannya, laki-laki dan perempuan yang banyak menyebut (nama) Allah, Allah Telah menyediakan untuk mereka ampunan dan pahala yang besar.

Perhiasan yang menghiasi kaum laki-laki mukmin dan perempuan mukminat yang terungkap dalam ayat ini adalah perhiasan takwa, tidak berkata dengan suara yang menggoda, merangsang, dan memancing birahi, tetap di dalam rumah (memelihara rumah), tidak keluar dalam situasi yang benar-benar perlu, tidak tabarruj, tidak buka-bukaan, mendirikan shalat, menunaikan zakat, tunduk dan menaati segala yang disyariatkan Allah dan taat kepaada rasul-Nya terhadap apa yang sampai kepadanya. 


\section{Relevansi Konsep Jilbab dengan Pendidikan Islam}

Salah satu aspek penting dan mendasar dalam pendidikan Islam adalah aspek tujuan. Dengan adanya tujuan, semua aktivitas dari gerak manusia jadi terarah dan bermakna. Tanpa tujuan semua aktivitas manusia akan terombang-ambing. Konsep jilbab dalam al-Qur'an di sini sangat relevan dengan tujuan tertinggi pendidikan Islam. Tujuan tertinggi dan terakhir ini pada akhirnya sesuai dengan tujuan hidup manusia dan peranannya sebagai ciptaan Allah, yaitu menjadi hamba Allah yang paling takwa, mengantarkan subjek didik sebagai khalifatullah fil ard (wakil Allah di bumi), dan untuk memperoleh kesejahteraan, kebahagiaan hidup di dunia sampai di akhirat. Hal ini sesuai dengan konsep al-Qur'an tentang jilbab pada kata la'allakum tuflikhun yang artinya supaya kamu beruntung. Sebagaimana yang diutarakan Ahmad Mustafa al-Maragi dalam Tafsir al-Maragi bahwa ayat ini terkandung do'a mudahmudahan kalian mendapatkan kebahagiaan di dunia dan akhirat. ${ }^{20} \mathrm{Hal}$ ini jika mereka benar-benar mengetahui konsep jilbab dan menjalankannya sesuai dengan yang diperintahkan oleh Allah Swt.

Tujuan tertinggi pendidikan Islam meliputi aspek kejiwaan yang lebih abstrak, yaitu filsafat hidup dan kepercayaan. Dengan kata lain pendidikan Islam secara filosofis berorientasi kepada nilai-nilai Islam yang bersasaran pada tiga dimensi hubungan manusia selaku khalifah di muka bumi, yakni sebagai berikut (a) menanamkan sikap hubungan yang seimbang dan selaras dengan Tuhannya, (b) membentuk sikap hubungan yang harmonis, selaras, dan seimbang dengan masyarakatnya, (c) mengembangkan kemampuan untuk menggali, mengelola, dan memanfaatkan kekayaan alam bagi kepentingan kesejahteraan hidupnya dan hidup sesamanya serta bagi kepentingan ubudiyah-nya kepada Allah dengan dilandasi sikap yang harmonis pula. ${ }^{21}$ Kesemuanya ini harus dilakukan manusia selama hidup di dunia sebagai bekal mereka untuk hidup di akhirat. Untuk mencapai semua itu maka Allah mengirimkan para Rasul-Nya untuk memperbaiki akhlak manusia di bumi agar mereka

\footnotetext{
${ }^{20}$ Ahmad Mustofa al-Maragi, Tafsir al-Maragi, Juz XVII, 182.

${ }^{21}$ Muzayyin Arifin, Filsafat Pendidikan Islam (Jakarta: PT. Bumi Aksara, 2005), 121.
} 
bisa mengekspresikan kesadaran religius dengan praktik-praktik yang berdasarkan al-Qur'an dan Hadis untuk mencari bekal hidup diakhirat nanti. Sebagaimana firman Allah di dalam al-Qur'an Surat al-Baqarah ([2]: 197) yang berbunyi, "Berbekallah, dan sesungguhnya sebaik-baik bekal adalah takwa." Hal ini sinkron dengan konsep al-Qur'an tentang jilbab, karena dalam ayat-ayat jilbab Allah tidak hanya mewajibkan jilbab bagi kaum wanita, tetapi juga mensyari'atkan adab-adab pergaulan dalam rumah tangga di luar rumah, adap pergaulan dalam satu rumah, serta adab-adab keluarga Nabi dan sifat-sifatnya kemudian mengharuskan kaum wanita untuk menutup aurat. Penutup aurat di sini bukan hanya pakain fisik (penutup lahir), tapi juga pakain takwa (penutup batin).

Tujuan pendidikan Islam, membentuk pribadi yang beriman dan bertaqwa, mengembangkan manusia yang baik, yaitu manusia yang beribadah dan tunduk kepada Allah Swt., serta mensucikan diri dari dosa dengan cara menjalankan ajaran-ajaran syariat secara global. Jika kita meneliti ajaran syariat secara komprehensif dengan menginduksikan seluruh hukumnya, maka kita akan menemukan bahwa seluruh hukum syariat dimaksudkan untuk merealisasikan suatu tujuan tertentu, dan tujuan itu tidak lain adalah kebahagiaan manusia dengan melindungi keselamatan mereka baik dikehidupan dunia maupun kehidupan akhirat. Jika ada salah satu hukum yang diabaikan, maka hal itu akan mengganggu dan mengacaukan tercapainya tujuan syariat secara keseluruhan. Sebagaimana yang telah diketahui bahwa hukum-hukum syariat secara keseluruhan dimaksudkan untuk mewujudkan kemaslahatan atau menghindarkan dari kerusakan. Kiranya bukan suatu yang asing bagi kita bahwa tujuan syari'at untuk mewujudkan kebaikan dan mencegah kerusakan itu direalisasikan dengan cara melindungi lima jenis harga diri, yaitu agama, akal, jiwa, harta, dan kehormatan. Rusaknya kehormatan apabila terjadi perzinaan dan pemerkosaan. Kerusakan pada harta terjadi apabila ada pencurian atau kleptomanisme. Kerusakan pada jiwa apabila terjadi pembunuhan. Kerusakan pada akal terjadi dengan mabuk, gila, dan penggunaan narkotika. Kerusakan pada agama terjadi pada kekafiran dan ateisme. Jika kita tahu bahwa syariat dimaksudkan untuk melindungi kemaslahatan dan menghindarkan kerusakan pada 
kelima jenis harga diri di atas, sejalan dengan tujuan ini, maka setiap item dari hukum syariat berfungsi sama. Upaya perlindungan ini bisa berlangsung secara optimal dengan mencegah terjadinya segala hal yang membawa kabaikan. Dari sini bisa dikatakan bahwa syariat tidak akan membiarkan satu pintu pun terbuka bagi kerusakan kecuali menutupnya, dan tidak menyediakan satu saranapun bagi timbulnya kerusakan kecuali melarangnya. Sebaliknya, syariat tidak membiarkan satu pintu pun bagi kemaslahatan kecuali membukanya, dan tidak membiarkan sarana yang mengantarkan kepada kebaikan kecuali membolehkannya. Misalnya, demi menjaga kehormatan, maka zina diharamkan karena menjadi simbol rusaknya kehormatan. Untuk itu, syariat menutup segala pintu yang dapat menyebabkan timbulnya perbuatan zina dan mencegah semua hal yang menjadi sarana timbulnya zina. Hal ini sejalan dengan konsep al-Qur'an tentang jilbab yang mensyariatkan kaum laki-laki untuk menahan pandangannya kepada wanita, begitu juga sebaliknya kaum wanita dilarang memandang laki-laki secara berlebihan agar mereka terhindar dari perbuatan zina atau segala sesuatu yang mendekatkan diri kepada lembah perzinaan. Oleh karenanya, Allah Swt. menetapkan beberapa hal sebagai berikut:

Pertama, Allah mengharamkan kita untuk memandang lawan jenis secara berlebihan dalam firman-Nya Q.S. an-Nur [34]: 31. Kedua, Allah mengharamkan persentuhan antara laki-laki dan perempuan, baik dengan jabat tangan atau lainnya selama keduanya tidak ada hubungan mahram atau lainnya. Ketiga, Allah Swt. mewajibkan hijab bagi perempuan. Peraturan-peraturan ini dimaksudkan untuk menjadikan manusia sebagai pribadi Muslim yang utuh menuju insan kamil. Dari satu sisi hukuman Islam mengekang zina dengan kekuatan, dan di sisi lain melindungi keadilan masyarakat terhadap fitnah. Sedangkan terhadap pengajaran moral, Islam membersihkan manusia dari kecenderungan yang mengarah pada perbuatan dosa. Hukum atau sanksi hukuman yang berat mengatur perilaku yang terlihat dengan nyata. Jadi, dalam kasus pendidikan, moral ditujukan untuk membasmi sisa-sisa cacat dan kecenderungan jahat tidak akan menjelmakan menjadi tindakan nyata yang dapat ditahan oleh kekuatan. Di samping itu beberapa aturan 
tertentu juga diterapkan untuk memperbaruhi dirinya sendiri, seperti latihan mengekang nafsu, atau menggunakan rasa malu untuk menolak diri melakukan kebatilan. Aturan-aturan ini telah dipergunakan untuk memperbaruhi sistem sosial sehingga kecenderungan jahat tidak akan menjelma dalam tindakan nyata. Penerapan langkah ini dalam rangka menuju terciptanya lingkungan sosial yang tidak memungkinkan terbesitnya keinginan-keinginan jahat dan gangguan ataupun keresahan emosional. Jadi, aturan-aturan pencegahan ini membantu memperlemah faktor-faktor yang mengarah pada anarki seksual dan membasmi segala bentuk ketaksenonohan yang mungkin akan membikin racun sisitem sosial.

\section{Tujuan Jilbab dalam Pendidikan Islam}

Berbeda dengan tujuan tertinggi yang lebih mengutamakan pendekatan filosofis, tujuan umum lebih bersifat empiris dan realistis. Tujuan umum berfungsi sebagai arah yang taraf pencapaiannya dapat diukur karena menyangkut perubahan sikap, perilaku, dan kepribadian subjek didik. Tujuan umum ini merupakan cita-cita hidup yang ditetapkan untuk dicapai melalui proses kependidikan dengan berbagai cara atau sistem, baik sistem formal, nonformal maupun informal. Tujuan ini dikatakan umum karena berlaku bagi siapa saja tanpa dibatasi ruang dan waktu, dan juga menyangkut diri subjek didik secara total. Tujuan umum pendidikan Islam berusaha mendidik individu mukmin agar tunduk, bertakwa dan beribadah dengan baik kepada Allah. Dengan kemampuan mengaktualisasikan potensi atau sumber daya insani berarti dia mampu merealisasikan diri (selfrelation) yakni menampilkan diri sebagai pribadi yang utuh (pribadi Muslim). Proses pencapaian realisasi diri tersebut dalam istilah psikologi disebut proses becoming, yakni proses menjadi diri dengan keutuhan pribadinya, sedangkan untuk sampai pada keutuhan pribadi diperlukan proses perkembangan tahap demi tahap yang disebut proses development. Tujuan pendidikan ini bukan lapangan psikologi pendidikan tetapi merupakan lapangan filsafat pendidikan yang mempelajari dan menentukan tujuan pendidikan, tetapi setelah 
tujuan itu ditentukan, maka timbullah suatu problem baru yang harus dipecahkan yaitu suatu problem yang berwujud bagaimanakah tujuan itu harus diperolehnya (dicapainya), cara-cara manakah yang sebaiknya ditempuh, di sinilah tugas psikologi pendidikan. Psikologi pendidikan harus mendapatkan cara-cara yang baik guna mencapai tujuan itu. ${ }^{22}$ Arifin menjelaskan bahwa tujuan proses pendidikan Islam adalah proses pendidikan yang berdasarkan ajaran Islam. ${ }^{23}$

Terkait dengan tujuan umum pendidikan Islam, konsep jilbab di sini menyiapkan kondisi psikologis untuk memerangi pengaruh hal-hal yang menyeret penyimpangan di luar diri, dan mendatangkan imunisasi di dalam diri pria dan wanita untuk melawan hal-hal itu. Hijab menyarankan kepada wanita agar ia menampilkan dirinya sebagai manusia, dan membantunya untuk mewujudkan hal itu dengan cara menyembunyikan dari penglihatan pesona kewanitaannya, ia (jilbab) juga menyarankan kepada pria, pada saat yang bersamaan, agar tidak memandang wanita kecuali sebagai manusia dengan cara memalingkan pandangannya dari daya tarik fisiknya. Demikianlah hijab merupakan sarana untuk menutup semua hal-hal yang dapat menciptakan kondisi penyimpangan dengan intensitas tinggi sehingga menjadikan manusia menjadi pribadi Muslim yang utuh. Untuk mencapai kepribadian Muslim yang utuh itu merupakan tujuan umum pendidikan Islam yang proses pencapaiannya melalui berbagai lingkungan atau lembaga pendidikan. Baik pendidikan keluarga, sekolah, masyarakat secara formal, non formal maupun informal. Pendidikan harus diarahkan mencapai pertumbuhan keseimbangan kepribadian manusia menyeluruh, melalui latihan jiwa, intelek, jiwa intelek, jiwa rasional, perasaan, dan penghayatan lahir. Karena itu pendidikan harus menyiapkan pertumbuhan manusia dalam segala seginya: spiritual, intelektual, imajinatif, jasmani, ilmiah, linguistik, baik individu maupun kolektif dan semua itu didasari motivasi mencapai kebaikan dan perfeksi. Tujuan akhir pendidikan Muslim itu terletak pada (aktivitas)

\footnotetext{
${ }^{22}$ Mustaqim \& Abdul Wahib, Psikologi Pendidikan (Jakarta: Rineka Cipta, 2010), 17.

${ }^{23}$ M. Arifin, Ilmu Pendidikan Islam: Suatu Tinjauan Teoritis dan Praktis berdasarkan Pendekatan Interdisipliner (Jakarta: Bumi Aksara, 2000), 224.
} 
merealisasikan pengabdian kemanusiaan seluruhnya. ${ }^{24}$

Dalam konsep al-Qur'an tentang jilbab ini, Allah Swt. memerintahkan agar kaum pria dan wanita menahan pandangan mereka agar terhindar dari perbuatan tercela. Hikmah menahan pandangan dapat menutup pintu kejahatan dan mencegah terjadinya perbuatan dosa. Karena biasanya dari pandangmemandang dapat menimbulkan akibatakibat negatif seperti kenakalan dan perbuatan yang tidak senonoh. Apalagi ketika seorang pria yang mempunyai penyakit dalam hatinya melihat sosok wanita yang sangat seksi atau mengenakan pakaian yang merangsang maka besar kemungkinannya laki-laki itu berkeinginan untuk melakukan seks, sebab dengan pakain mini atau yang seksi-seksi dan sejenisnya merupakan unsur pembangkit naluri seksual secara langsung karena adanya gambar nyata darinya atau gambar imajinatif. Untuk itu dalam Surat an-Nur (24]: 31) selain perintah menahan pandangan bagi kaum pria dan wanita, Allah memberikan perintah tambahan kepada kaum wanita agar tidak menampakkan perhiasannya. Yang dimaksud perhiasan di sini adalah tempat-tempat diletakkannya perhiasan itu seperti telinga, leher, lengan, bukan bentuk perhiasannya seperti kalung, gelang, anting, dalam kata lain Allah mewajibkan bagi kaum wanita untuk lebih bisa menutup anggota badannya secara keseluruhan kecuali wajah dan telapak tangan. Akan tetapi, dalam ayat berikutnya an-Nur ([24]: 60), Allah memberikan dispensasi kepada perempuan-perempuan tua yang telah terhenti masa haid dan melahirkan, mereka boleh menanggalkan jilbabnya dengan tidak bermaksud untuk menampakkan perhiasannya. Hal ini diperbolehkan bagi wanita tua yang sudah tidak memiliki nafsu terhadap laki-laki dan laki-laki juga tidak memiliki ketertarikan kepadanya yang disebabkan karena usianya yang sudah tua dan atau bisa juga karena sebab yang lain semisal penampilannya yang buruk atau keadaan wanita yang tidak lagi menjalankan fungsi yang semestinya ia jalankan, semisal pemenuhan kebutuhan seksual.

Dalam ayat yang lain Q.S. al-Ahzab ([46]: 32-33), ayat ini menerangkan bahwa untuk menghindari perbuatan yang buruk, Allah

\footnotetext{
${ }^{24}$ Sudiono, Ilmu Pendidikan Islam, Jilid 1, (Jakarta: Rineka Cipta, 2002), 41.
} 
memerintahkan kepada istri-istri Nabi juga kaum Muslimah pada umumnya agar tidak melembutkan suara saat bercakap dengan laki-laki yang bukan mahram. Walaupun wanita menurut kodratnya memiliki suara yang lembut. Atas dasar itu, maka larangan di sini harus dipahami dalam arti membuat-buat suara menjadi lebih lembut lagi melebihi kodrat dan kebiasaannya berbicara. Sebab cara bicara demikian, bisa dipahami sebagai menampakkan kemanjaan kepada lawan bicara yang pada gilirannya dapat menimbulkan hal-hal yang tidak direstui Agama. Ayat ini juga melarang kaum wanita berdandan seperti orang-orang jahiliyah dulu. Dari situ dapat diketahui bahwa di dalam al-Qur'an telah dijelaskan secara detail bahwa jilbab adalah pakaian keagungan wanita Muslimah yang dapat melindungi dan juga menjanjikan kebaikan jika Muslimah itu mampu memahami makna jilbab yang sesungguhnya dan mau mengamalkannya dalam kehidupan sehari-hari. Akan tetapi, hal ini sangatlah tidak mudah, perlu adanya pembiasaan diri, jikalau asalnya bukan seorang yang pemurah, maka hendaklah ia membiasakannya. Begitu juga seandainya ia bukan seorang yang bersifat rendah hati, pemurah maka hendaklah ia paksakan dirinya agar terbiasa. Begitu juga dengan sifat-sifat yang lainnya di atas dengan kebalikannya hingga tercapai tujuannya dengan cara menekuni ibadah, menentang syahwat, membaguskan bentuk-bentuk batin serta menyenangkan hati terhadap Allah Swt.

Pembiasaan ini merupakan aspek penting untuk memantapkan akhlak seseorang, karena dengan pembiasaan orang akan mengalami suatu tindakan langsung sehingga akan menjadi perekat antara tindakan akhlak dengan diri seseorang. Sebagaimana dijelaskan oleh Nasirudin, "Pembiasaan berfungsi sebagai penguat objek pemahaman yang telah masuk ke dalam hatinya. Semakin lama seseorang mengalami suatu tindakan maka tindakan itu akan semakin rekat dan akhirnya akan menjadi sesuatu yang tak terpisahkan dari diri dan kehidupannya." Dan akhirnya tindakan itu akan menjadi akhlak. Pembiasaan juga bisa berfungsi sebagai penjaga akhlak yang sudah melekat pada diri seseorang. Semakin tindakan akhlak itu dilakukan secara terus-menerus, maka akhlak yang sudah melekat itu akan semakin terjaga. Seseorang yang semakin intens 
di dalam melaksanakan akhlak maka berarti dia telah munutup cela masuknya hawa nafsu yang ingin merobohkan akhlak yng telah terbangun itu. Itulah sebabnya tindakan yang paling disukai Allah adalah tindakan yang terus menerus (dawam). Pembiasaan juga akan memunculkan pemahaman-pemahaman yang lebih dalam dan luas, sehingga seseorang semakin yakin dan mantap di dalam memegang objek akhlak yang telah diyakini itu. Bahkan seseorang bisa merasa kehilangan seandainya dalam suatu waktu ia meninggalkannya. ${ }^{25}$

Sebagai contoh, seseorang yang telah membiasakan dirinya untuk sholat berjama'ah tepat waktu, ketika dia harus berjama'ah di akhir waktu karena sesuatu sebab, dia akan merasa kehilangan sesuatu yang sangat berharga darinya. Hal ini terjadi karena pembiasaan tersebut. Pembiasaan ini dapat mendorong orang untuk istiqomah dalam melaksanakan berbagai hal, tidak terkecuali pula dengan mengenakan jilbab. Untuk itu membiasakan diri untuk berjilbab dan memohon kepada Allah agar dikaruniai sifat istiqomah dapat menghindarkan diri dari patah semangat, kembali kepada sifat jahiliyah dan tidak mengenakan jilbab lagi sebagaimana orang-orang yang mengenakan jilbab seenaknya sendiri. ${ }^{26}$ Dari pemaparan di atas dapat diketahui dengan jelas bahwa relevansi konsep al-Qur'an tentang jilbab dengan tujuan pendidikan Islam yaitu kecocokkannya dalam pembentukan akhlak manusia yang mengarah pada kepribadian Islam dengan selalu mempertebal iman dan takwa sehingga menjadi manusia yang berguna bagi negara dan agama serta mencapai kebahagiaan dunia dan akhirat. Dalam pembentukan kepribadian manusia tersebut keduanya saling berkaitan. Konsep al-Qur'an tentang jilbab menjadi pendukung tercapainya tujuan pendidikan Islam.

\footnotetext{
${ }^{25}$ Nasirudin, Pendidikan Tasawuf (Semarang: Rasail Group Media, 2010), 39.

${ }^{26}$ Betapa banyak kita temukan fakta tentang banyaknya teman, kerabat, dan masyarakat yang mengenakan jilbab sekena mereka. Mereka memakai dan melepaskan kembali bila sudah tidak berkenan memakainya. Burhan Sodiq, Engkau Lebih Cantik dengan Jilbab (Sukoharjo: Samudera, 2007), 127.
} 


\section{Relevansi Konsep Jilbab dengan Tujuan Khusus}

Tujuan ini bersifat relatif sehingga dimungkinkan untuk diadakan perubahan dimana perlu sesuai dengan tuntutan kebutuhan, selama tetap berpijak pada kerangka tujuan tertinggi, terakhir dan umum itu. Tujuan operasional ini merupakan tujuan praktis yang akan dicapai dengan sejumlah kegiatan pendidikan tetentu. Satu unit kegiatan pendidikan dengan bahan-bahan yang sudah dipersiapkan dan diperkirakan akan mencapai tujuan tertentu sesuai dengan program yang telah ditentukan dalam kurikulum. Tujuan khusus meliputi aspek psikomotorik karena dalam tujuan operasional ini lebih banyak dituntut oleh anak didik mengenai kemampuan dan keterampilan tertentu. Sifat operasionalnya yang lebih ditonjolkan dari pada sifat penghayatan dan kepribadian. Misalnya pada masa permulaan, yang penting adalah anak didik mampu terampil berbuat baik, baik perbuatan lidah (ucapan) atau pun perbuatan anggota badan lainnya. Kemampuan dan keterampilan yang dituntut pada anak didik, merupakan sebagian kemampuan dan keterampilan insan kamil dalam ukuran anak, yang manuju pada bentuk insan kamil yang semakin sempurna (meningkat). Anak harus terampil melakukan ibadah (sekurang-kurangnya ibadah wajib) meskipun belum memahami dan menghayati ibadah itu. Kaitannya dengan jilbab di sini, jilbab dalam al-Qur'an tidak hanya secara lahiriah saja tetapi juga akhlaki yaitu para pemakai jilbab harus melengkapinya dengan pakaian takwa. Jilbab dapat memotivasi diri untuk melakukan sesuatu dengan baik, selalu mendekatkan diri kepada Allah jika pemakainya benar-benar mengetahui makna jilbab yang sesungguhnya. Abdul Halim Abu Syuqqah menjabarkan esensi jilbab yang menyeluruh, yaitu:

1. Pakaian yang sempurna itu, lebih-lebih untuk penjagaan diri, dapat membantu mendewasakan pikiran wanita dan mengembangkannya, kemudian mengaktifkan dan mengkretifkannya.

2. Pakaian yang sempurna itu membantu menjaga dan memelihara hati wanita sehingga selalu sadar dan gemar kepada kebaikan.

3. Pakaian yang sempurna itu membantu untuk memelihara harga diri dan kemuliaan wanita di manapun ia berada 
4. Terakhir, pakaian yang sempurna itu membant wanita melaksanakan tugas dan tanggung jawabnya mulai dari mengurus rumah tangga hingga terlibat dan berperan serta dalam membangun umatnya, baik dalam kegiatan sosial politiknya maupun dalam tugas-tugas yang menjadi kebutuhannya atau kebutuhan mesyarakat. ${ }^{27}$

Untuk itu para manusia perlu diberi kejelasan bahwa ayat-ayat konsep al-Qur'an tentang jilbab ini berbicara mengenai pakaian atau busana yang sepatutnya dipakai oleh orang-orang beriman agar berbeda dengan yang tidak beriman atau singkatnya mengenai busana Muslim dan Muslimah. Sebagaimana dijelaskan sebelumnya bahwa berpakaian adalah fitrah, karena itu pada hakikatnya manusia yang sehat fitrahnya, tidak akan telanjang. Meski demikian, tidak semua orang yang berpakaian, masuk dalam kategori berpakaian dalam Islam. Hal ini seperti ditegaskan dalam ayat-ayat bahwa berjilbab sekalipun belum tentu sesuai dengan ayat ini, bila jilbabnya belum diulurkan seperti kebanyakan jilbab gaul sekarang ini, lebih-lebih yang tidak pakai jilbab. Dengan memahami konsep al-Qur'an tentang jilbab dan relevansinya dengan tujuan pendidikan Islam tersebut manusia akan mampu merealisasikan tujuan hidupnya di muka bumi, yaitu tugas untuk senantiasa melestarikan tatanan kehidupan yang harmonis, sebagaimana yang telah diciptakan oleh Allah Swt. Sebab konsep al-Qur'an tentang jilbab terefleksikan dalam tujuan pendidikan Islam, keduanya bermuara pada pengabdian seorang hamba kepada Allah Swt.

\section{Penutup}

Konsep jilbab dalam al-Qur'an yaitu memerintahkan kepada kaum wanita untuk menutupi kepala, leher hingga dada mereka dengan jilbab, juga menyeru kepada kaum lelaki mukmin dan wanita mukminat untuk menghiasi diri mereka dengan perhiasan takwa, tidak berkata dengan

\footnotetext{
${ }^{27}$ Abdul Halim Abu Syuqqah, Wanita dalam Islam, terj. As’ad Yasin (Jakarta: Gema Insani Press, 2000), 35.
} 
suara menggoda, merangsang, dan memancing syahwat, tetap di dalam rumah, tidak keluar kecuali dalam situasi yang benar-benar perlu, tidak tabarruj, tidak buka-bukaan, mendirikan shalat, menunaikan zakat, tunduk dan mentaati segala yang disyariatkan Allah kepada rasul-Nya terhadap apa yang sampai kepadanya. Relevansi konsep al-Qur'an tentang jilbab dengan tujuan pendidikan Islam yaitu kecocokannya dalam pembentukan akhlak manusia yang mengarah pada kepribadian Islam dengan selalu mempertebal iman dan takwa sehingga menjadi manusia yang berguna bagi negara dan agama, serta mencapai kebahagiaan dunia dan akhirat. Dalam pembentukan kepribadian manusia tersebut keduanya saling berkaitan.

\section{Daitar Pustaka}

Achmadi. Ideologi Pendidikan Islam. Yogyakarta: Pustaka Pelajar, 2005. al-Farmasi, Abd al-Hayy. Metode Tafsir Mawdhu'i: Suatu Pengantar. Jakarta: Raja Grafindo Persada, 1996.

al-Syaikh Abdullah bin Muhammad bin Abdurrahman bin Ishaq. Tafsir Ibnu Katsir, terj. M. Abdul Ghoffar E. M \& Abu Ihsan al-Atsari. Jakarta: Puataka Imam Asy-Syafi'i, 2008.

al-Maliki, Muhammad Alawi. Ilmu Ushul Hadis, terj. Adnan Qohar. Yogyakarta: Pustaka Pelajar, 2009.

al-Maragi, Ahmad Mustofa. Tafsir al-Maragi, terj. Bahrun Abu Bakar.

Cet. II. Semarang: PT. Karya Toha Putra, 1992.

Ali, Muhammad Daud. Pendidikan Agama Islam. Jakarta: PT. Raja Grafindo Persada, 2005.

al-Jarullah, Abdullah bin Jarullah bin Ibrahim. Inilah Tanggung Jawab Wanita Muslimah, terj. M. Abdul Ghoffar. Bogor: Pustaha Imam Syafi'i, 2004.

al-Qushairi, Imam Abu Husain Muslim bin Hujaj. Shahih Muslim, Jilid I.

Beirut: Dar al-Kutub al-Ilmiah, 2008. 
al-Taliyadi, Abdullah. Astagfirullah Aurat. Yogyakarta: Diva Press, 2008. AR, Fadhal. Al-Quran dan Terjemahnya. Surabaya: Mekar, 2004.

Arief, Armai. Pengantar Ilmu dan Metodologi Pendidikan Islam. Jakarta: Ciputat Press, 2002.

Arifin, Muzayyin. Filsafat Pendidikan Islam. Jakarta: PT. Bumi Aksara, 2005.

As-Sajstani, Abu Dawud Sulaiman bin al-Asy'ats. Sunan Abu Dawud. Beirut: Darul Fikri, 1994.

Awaliyah, Abdurrahman. Gaya Hidup Wanita Islam, terj. Agus Efendi \& Awaliyah Abdurrahman. Bandung: Mizan, 1994.

Azwar, Saifudin. Metode Penelitian. Cet. III. Yogyakarta: Pustaka Pelajar, 2001.

Darajat, Zakiah. Ilmu Pendidikan Islam. Cet. III. Jakarta: Bumi Aksara, 2011.

Departemen Agama RI. al-Quran dan Tafsirnya. Jakarta: Lentera Abadi, 2010.

Departemen Pendidikan Nasional. Kamus Besar Bahasa Indonesia. Edisi III. Jakarta: Balai Pustaka, 2005.

Suryadilaga, M. Alfatih, et.al. Metodologi Ilmu Tafsir. Yogyakarta: Teras, 2005.

Ghafur, Wahyono Abdul. Tafsir Sosial. Yogyakarta: eLSAQ Press, 2005.

Hadi, Sutrisno. Metodologi Research. Jilid 1. Yogyakarta: Andi, 2001.

Halim Abu Syuqqah, Abdul. Wanita dalam Islam. terj. As'ad Yasin. Jakarta: Gema Insani Press, 2000.

Haqani, Lukman. Aku Bukan Wanita Muslimah: Jebakan-jebakan yang Menghancurkan Identitas Muslimah. Bandung: Pustaka Ulumudin, 2004.

Husain, Syed Sajjad and Syed Ali Ashraf. Crisis in Muslim Education. Jeddah: Horder \& Stoughton, t.t. 
Jalaludin. Psikologi Agama. Jakarta: PT. Raja Grafindo Persada, 2001.

Junaidi, Akhmad Arif. Pembaruan Metodologi Tafsir al-Qur'an. Semarang: Gunung Pati, 2001.

Kementerian RI. Al-Qur'an dan Tafsirnya. Jakarta: Lentera Abadi, 2010.

Khalik, A. Chaeridji Abd. 'Ulum al-Quran. Jakarta: Diadit Media, 2007.

Khalil, Rasyad Hasan. Tarikh Tasyri'. Jakarta: Bumi Aksara, 2009.

M. A. Muhaimin \& Abdul Mujib. Pemikiran dan Pendidikan Islam. Bandung: Trigenda Karya, 1993.

Matsna, Moh. Pendidikan Agama Islam Al-Quran Hadis. Semarang: PT. Karya Toha Putra, 2010.

Maududi, Abul A'la. Jilbab Wanita dalam Masyarakat Islam. terj. Mufid Ridho. Bandung: Marja, 2005.

Moleong, Lexy J. Metodologi Penelitian Kualitatif. Bandung: Remaja Rosdakarya, 2009.

Muhadjir, Noeng. Metodologi Penelitian Kualitatif, Cet. VII. Jakarta: Rake Sarasin, 1996.

Muhaimin. Paradigma Pendidikan Islam: Upaya Mengefektifkan Pendidikan Agama Islam di Sekolah. Bandung: PT. Remaja Rosdakarya, 2002.

Muhammad, Sa'ad Shadiq. Harkat Wanita dalam Islam. Malang: alQayyim, 2004.

Muthahhari, Murtadha. Hijab Gaya Hidup Wanita Islam, terj. Agus Efendi \& Awaliyah Abdurrahman. Bandung: Mizan. 1994.

Nasirudin. Pendidikan Tasawuf. Semarang: Rasail Group Media, 2010.

Nur, Ahmad Fatkhi. "Studi Analisis Terhadap Muhammad Syahrur Tentang Memakai Jilbab bagi Wanita." Skripsi. Semarang: Perpustakaan Fakultas Syari'ah IAIN Walisongo, 2005.

Partanto, Pius A \& M. Dahlan al-Barry. Kamus Ilmiah Populer. Surabaya: Arkola, t.t. 
Rus, Abidin ibnu. Pemikiran al-Ghazali Tentang Pendidikan. Yogyakarta: Pustaka Pelajar, 1998.

Shaleh, Qamaruddin, et.al. Asbabun Nuzul: Latar Belakang Historis Turunnya Ayat-ayat al-Qur'an. Cet. III. Bandung: CV. Diponogoro, tt.

Shadiq, Burhan. Engkau Lebih Cantik dengan Jilbab. Sukoharjo: Samudera, 2007.

Shihab, Quraish. Tafsir al-Misbah. Volume II. Jakarta: Lentera Hati. 2002.

Sudiyono. Ilmu Pendidikan Islam. Jilid 1. Jakarta: Rineka Cipta, 2009.

Supriyati, "Jilbab Menurut Quraish Shihab dan Implikasinya Terhadap Bimbingan Muslimah dalam Berbusana: Telaah Terhadap Buku Jilbab Pakaian Wanita Muslimah." Skripsi. Fakultas Dakwah IAIN Walisongo, 2006.

Sya'rawi, Syeikh Mutawalli. Problematika Wanita. Jakarta: Iqra' Insan Press, 2003.

Syuqqah, Abdul Halim Abu. Wanita dalam Islam, terj. As'ad Yasin. Jakarta: Gema Insani Press, 2000.

Tafsir, Ahmad. Ilmu Pendidikan Perspektif Islam. Bandung: Remaja Rosdakarya, 1992.

Thahan, Mahmud. Ilmu Hadis Praktis, terj. Abu Fuad. Bogor: Pustaka Thariqul Izzah, 2006.

Tim Redaksi. al-Quran al-Karim. Solo: Qomari, t.t.

Udhiah, Sya'adatul. "Konsep Aurat Wanita dalam al-Qur'an: Studi Komparatif Menurut al-Qurtubi, Hamka, dan Muhammad Sahrur." Skripsi. Semarang: Perpustakan Fakultas Ushuluddin IAIN Walisongo, 2004.

Wahib, Mustaqim dan Abdu. Psikologi Pendidikan. Jakarta: Rineka Cipta, 2010.

Zed, Mestika. Metode Penelitian Kepustakaan. Jakarta: Yayasan Obor Indonesia, 2008. 